\title{
Forewarning model for sunflower thrips (Thrips palmi Karny) in western Maharashtra scarcity zone
}

\author{
V. B. AKASHE, J. D. JADHAV, V. R. BAVADEKAR, P. B. PAWAR and V. M. AMRUTSAGAR \\ Zonal Agriculture Research Station, Solapur (MS), India. \\ Email:vbakashe@gmail.com
}

\begin{abstract}
Field experiments were carried out with the sunflower variety Bhanu/SS-56 to study the effect of weather parameters on thrips (Thrips palmi Karny) population at Zonal Agriculture Research Station, Solapur (MS) during kharif seasons for ten consecutive years (2004 to 2013). The crop was sown during $15^{\text {th }}$ June to $15^{\text {th }}$ July in different yeas, which is normal sowing period at Solapur. The thrip population was positively correlated with maximum temperature while it was negatively correlated with $\mathrm{RH}-\mathrm{I}, \mathrm{RH}-\mathrm{II}$ and rainfall. The eight years (2004 to 2011) data were used for development of model, which was validated with experimental data of two years (2012 and 2013). The model explained the incidence of thrips on sunflower to an extent of $88 \%$. Hence, this model can be used for predicting the incidence of thrips on sunflower.
\end{abstract}

Key words: Forewarning model, validation, sunflower, thrips.

Sunflower (Helianthus annus L.) is one of the important edible oilseed crops cultivated in different parts of the world. In India it is grown in an area of 7.06 lakh hectares with production of 4.70 lakh tonnes and productivity of $666 \mathrm{~kg} \mathrm{ha}^{-1}$. Maharashtra, Karnataka and Andhra Pradesh account for $85.6 \%$ area and $90 \%$ of production with productivity of around $600 \mathrm{~kg} \mathrm{ha}^{-1}$ (Anonymous, 2014).

Insect pests and diseases are the major production constraints in traditional sunflower areas (Basappa and Prasad, 2005). Thrips infestation has now drawn great attention due to its association with sunflower necrosis disease. The intensity of disease has been reported to range from 2 to $100 \%$ causing the seed yield losses as high as 89 $\%$ under severe condition (Anonymous, 2001). However, no attempt has been made to quantify the effect of weather parameters on sunflower thrips. The present study has been undertaken to develop forewarning model for the prediction of sunflower thrips.

\section{MATERIALS AND METHODS}

Field experiments were conducted at the research farm of Zonal Agriculture Research Station, Solapur (75 $56^{\prime}$ $\mathrm{E}, 17^{\circ} 41^{\prime} \mathrm{N}$ ) during kharif season for ten consecutive years (2004 to 2013). The untreated seeds of sunflower variety Bhanu/SS-56 was sown under normal sowing conditions ( $15^{\text {th }}$ June to $15^{\text {th }}$ July) every year at spacing of $45 \times 30 \mathrm{~cm}$ in randomized blocks of $200 \mathrm{~m}^{2}$ with three replications. The crop was grown with all standard recommended agronomic practices under the rainfed situations.

Five plants in each block were selected and tagged to monitor the thrip incidence and its development. The observations on thrip count commencing from $30^{\text {th }}$ meteorological week upto 39 meteorological week were recorded on a leaf (average of 3 leaves $i$. e. top, middle and bottom) per plant on five randomly selected plants in each block at weekly interval during cropping seasons of every year. The different weather parameters were recorded daily for the same corresponding crop period from the field meteorological observatory. Weekly mean weather parameters of eight years (2004-2011) were correlated with thrips population and regression equation was developed to predict thrips population. Two year (2012 and 2013) were used to predict and validate the model.

\section{RESULTS AND DISCUSSION}

The mean population of thrips summarized in Table 1 revealed that under normal sowing condition the sunflower thrip occurrence during kharif season was started during 29-30 ${ }^{\text {th }}$ meteorological week which survived on the crop upto $38-39^{\text {th }}$ meteorological week. However, maximum temperature $\left(31-32^{\circ} \mathrm{C}\right)$, RH-I (85-86\%), RH-II (56-67\%) and rainfall $(13-28 \mathrm{~mm})$ during $32^{\text {nd }}-34^{\text {th }}$ meteorological week favoured the more thrips multiplication and its further spread as well (11-12 thrips/leaf/plant).

Thrip population was positively correlated with the maximum temperature while it was negatively correlated 
Table 1: Mean weather parameters and thrips population of sunflower along with correlation coefficient (mean of 2004 to 2011).

\begin{tabular}{lccccc}
\hline Meteorological week & Thirps/Plant & $\mathrm{T}_{\max }\left({ }^{\circ} \mathrm{C}\right)$ & $\mathrm{RH}-\mathrm{I}(\%)$ & $\mathrm{RH}-\mathrm{II}(\%)$ & $\mathrm{RF}(\mathrm{mm})$ \\
\hline 30 & 9.83 & 33.6 & 83 & 58 & 20.7 \\
31 & 10.97 & 31.3 & 87 & 67 & 50.0 \\
32 & 11.82 & 31.1 & 86 & 67 & 28.8 \\
33 & 12.32 & 31.2 & 85 & 62 & 13.7 \\
34 & 11.40 & 32.4 & 85 & 56 & 23.6 \\
35 & 9.95 & 32.0 & 88 & 58 & 47.8 \\
36 & 7.83 & 31.7 & 87 & 62 & 44.6 \\
37 & 6.27 & 31.3 & 89 & 65 & 44.4 \\
38 & 5.04 & 31.5 & 90 & 62 & 36.0 \\
39 & 3.07 & 31.5 & 89 & 66 & 34.9 \\
Mean & - & 31.8 & 86.9 & 62.3 & 34.5 \\
Correlation coefficient & - & $\mathbf{0 . 1 1 9}$ & $\mathbf{- 0 . 7 4 4 * *}$ & $\mathbf{- 0 . 2 5 7}$ & $\mathbf{- 0 . 3 1 9}$ \\
Significance level & $5 \%$ & 0.63 & & & \\
& $1 \%$ & 0.73 & & & \\
\hline
\end{tabular}

Table 2: Observed and predicted thrips incidence by using linear regression equation (Pooled 2012 and 2013)

\begin{tabular}{lcccc}
\hline Meteorological week & \multicolumn{4}{c}{ Thrip population/leaf/plant } \\
Observed & Predicted & Deviation/Residuals & Standardized residual \\
\hline 30 & 8.1 & 8.3 & -0.1 & 1.0 \\
31 & 8.1 & 15.0 & -6.9 & -0.2 \\
32 & 10.3 & 17.5 & -7.2 & -0.7 \\
33 & 10.8 & 12.7 & -1.9 & 0.8 \\
34 & 10.5 & 12.4 & -1.9 & 0.7 \\
35 & 8.2 & 19.2 & -11.0 & -1.3 \\
36 & 6.3 & 14.5 & -8.1 & -0.7 \\
37 & 5.0 & 10.0 & -5.0 & 0.0 \\
38 & 3.3 & 5.6 & -2.2 & 0.5 \\
39 & 1.7 & 6.3 & -4.5 & 0.1 \\
& MAE & 5.8 & & \\
& MBE & 4.9 & & \\
\hline
\end{tabular}

with morning relative humidity, evening relative humidity and rainfall (Table 1). It seems that the increased temperature favours the thrips population built up on sunflower. These weather parameters contributed significantly for the thrip incidence and its further spread under normal sowing situation. These weather parameters were used to develop the forewarn model for sunflower thrips. The equation thus developed explained $88 \%$ variation in thrips population.
Analysis of central tendencies of weather parameters revealed that $31.8 \pm 3.9$ maximum temperature, $87.0 \pm 2.0$ relative humidity morning, $62.0 \pm 0.5$ relative humidity evening and $34.5 \pm 0.1$ rainfall are highlycongenial for the multiplication of thrips from $1^{\text {st }}$ week of August to $2^{\text {nd }}$ week of September $\left(32^{\text {nd }}\right.$ to $36^{\text {th }}$ meteorological week).

THRIPS $=327.74-3.95 \times \mathrm{T}_{\max }-1.97 \times \mathrm{RH}-\mathrm{I}-0.42 \times \mathrm{RH}-$ $\mathrm{II}+0.11 \times \mathrm{RF}\left(\mathrm{R}^{2}=0.88\right)$ 


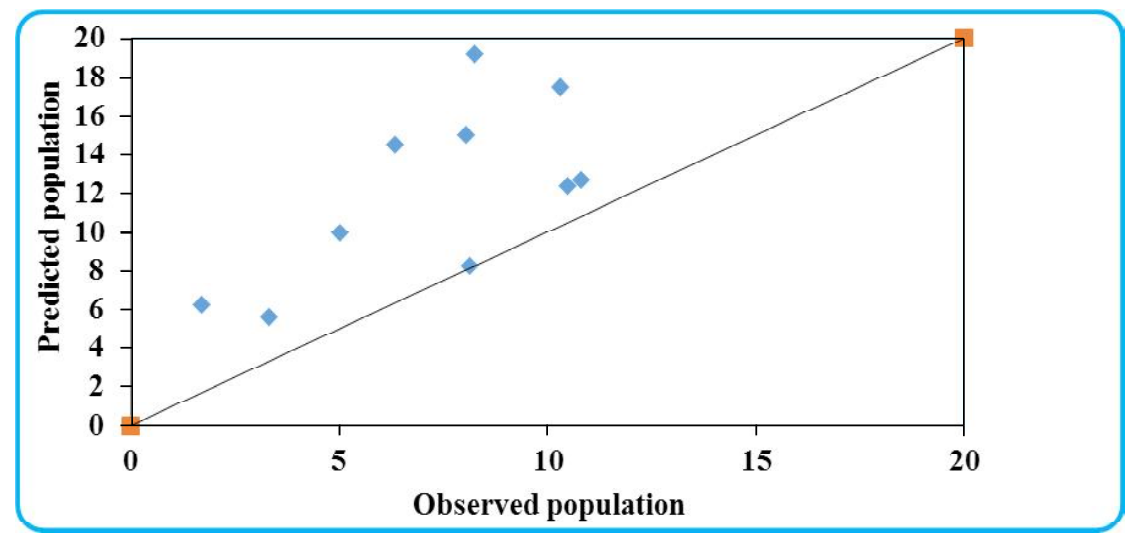

Fig. 1: Observed and predicted thrips population during 2012 and

Where,

$$
\begin{array}{ll}
\text { THRIPS } & =\text { Thrip population }\left(\text { Nos. plant }{ }^{-1}\right), \\
\mathrm{T}_{\max } & =\text { Maximum temperature }\left({ }^{\circ} \mathrm{C}\right), \\
\text { RH-I } & =\text { Morning relative humidity }(\%), \\
\text { RH-II } & =\text { Evening relative humidity }(\%), \\
\text { RF } & =\text { Rainfall }(\mathrm{mm}) .
\end{array}
$$

The model has validated with the two year (2012 and 2013) observed data on thrips (Table 2). The standardized residual values estimated based on deviation between actual observed and predicted thrips are in between -3.00 and +3.00 which indicated the suitability of model for thrip prediction irrespective of the weather parameters. Hence, the equation is best fitted for thrip prediction. The other statistical parameters (MAE, MBE and RMSE) also suggested under estimation through mean of two years (2012 and 2013) as showed in Fig 1.

Katti et al. (2011) noticed that the thrips population on sunflower was higher in the kharif season between JuneAugust first week. They also reported that the thrips were found to have significant and positive correlation with maximum temperature. This justifies the results of the present investigations. The weather based forewarning models for safflower aphid (Uroleucon compositae T.) were developed by Akashe et al. (2013).

\section{CONCLUSIONS}

It is advisable to have early sowing of kharif sunflower in the month of June immediately after the onset of monsoon so as to avoid the peak infestation period of thrip incidence to early/vulnerable stages of the crop. We had forecast the model/regression equation to forewarn the incidence of sunflower thrip to undertake the control action as soon as pest occurs. The correlation and regression analysis clearly indicated the importance of weather factors in the prediction of thrips on sunflower. The linear regression model was found to be precise for the prediction of incidence and further spread of sunflower thrips. Thus, this model may be utilized in the Agro-advisories for thrips prediction on sunflower and thereby controlling the sunflower necrosis virus disease in time.

\section{REFERENCES}

Akashe, V. B., Gud, M.A., Shinde, S. K., Jadhav, J. D., Bavdekar, V.R. and Kadam, J.R. (2013). Weather based forewarning models for safflower aphid (Uroleucon compositae $\mathrm{T}$.) in the scarcityzone of Maharashtra.J. Agromet., 15(Spl. Issue-I): 1-5.

Anonymous. (2001). Annual progress Report: Sunflower, 20002001. Directorate of Oilseeds Research,Hyderabad, pp: 49-50.

Anonymous. (2014). Directorate of Economics and Statistics, Department of Agriculture and Cooperation, Agriculture Statistics at a Glance 2014. pp: 88 .

Basappa, H. and Santha Lakshmi Prasad, M. (2005). A bookInsect pests and diseases of sunflower and their management. Directorate of Oilseeds Research, Hyderabad, pp: 80.

Katti, P., Naganagoud, A., Reddy, M. and Chandranath, H. T. (2011). Seasonal incidence of sunflower thrips and their relationship with weather factors. Plant Archives., 11(1): 339-341. 